НАУКОВИЙ ВІСНИК

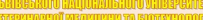

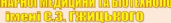
tific messenger of 2. 10 What (I)

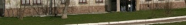
Том 21 № 92 2019

\section{Науковий вісник Дьвівського національного університету} ветеринарної медицини та біотехнологій імені С.3. Гжицького. Серія: Харчові технологіі

\author{
Scientific Messenger of Lviv National University
} of Veterinary Medicine and Biotechnologies.

Series: Food Technologies

UDC 004.344.3:637.56

\title{
Usage of chia seeds in the composition of dietary semi-finished minced products
}

\author{
N. Golembovskaya \\ Article info \\ Received 05.09.2019 \\ Received in revised form \\ 07.10 .2019 \\ Accepted 08.10.2019
}

National University of Life and Environmental Sciences of Ukraine, Kyiv, Ukraine

National University of Life and Environmental Sciences of Ukraine Heroyiv Oborony str., 15, Kyiv, 03041 , Ukraine

Tel.: + 38-096-206-62-76

E-mail: natashagolem-

bovska@gmail.com

Golembovskaya, N. (2019). Usage of chia seeds in the composition of dietary semi-finished minced products. Scientific Messenger of Lviv National University of Veterinary Medicine and Biotechnologies. Series: Food Technologies, 21(92), 19-22. doi: 10.32718/nvlvet-f9204

The article deals with the results of sensory analysis of semi-finished minced fish products with nontraditional raw materials (seeds of chia) by the flavor profile method, and establishing their compliance with the hypothetical standard. It is shown the expediency of its use to assess the overall impression about the combination of freshwater fish with plant materials for the diversification of biologically valuable food products. The obtained positive results of organoleptic studies have shown the expediency of combining the chia seeds with freshwater fish, and it is proved by high indicators of such descriptors as: the overall impression, harmonious, fishy, sweet-salty taste. As for the consistency, fish cutlets are plastic and dense on the cut. The article deals with the results of the chemical composition, organoleptic evaluation and physical and chemical changes in semi-finished minced products with the addition of nontraditional raw materials and the establishment of their shelf life. The expediency of combining a freshwater fish with plant material to expand the range of biologically valuable food products is presented in the article. The research has established that the use of non-traditional raw materials in a production of semi-finished minced products allows not only to improve the technology of production, but also to solve the problem of obtaining the product of a high nutritional value. The author found that the developed technology of production of semi-finished fish products will significantly expand the range of products of functional purpose based on natural components, which will allow, to some extent, to expand the actual problem of processing raw materials from domestic reservoirs in Ukraine.

Key words: cutlet, non-traditional raw materials, chia, semi-finished products, organoleptic evaluation, sensory characteristics, flavor, descriptors, profilogram.

\section{Використання насіння чіа у складі дістичних січених напівфабрикатів}

\author{
Н.В. Голембовська
}

Національний університет біоресурсів та природокористування Украӥни, м. Київ, Украӥна

У статті наведені результати сенсорного аналізу січених напівфабрикатів з нетрадиційною сировиною (насіння чіа) методом профілю флейвору і встановлення їх відповідності гіпотетичному еталону. Показано доцільність його використання для оцінки загального враження поєднання прісноводної риби з рослинною сировиною для розщирення асортименту біологічно цінної харчової продукиіі. Отримані позитивні результати органолептичних досліджень показали доцільність поєднання насіння чіа з прісноводною рибою, про щчо свідчать високі показники таких дескрипторів, як загальне враження, гармонійний, рибний, солодкуватосолонуватий смак. За показником консистениії рибні котлети пластичні та щуільні на розрізі. У статті наведено результати хімічного складу, органолептичної очінки та фізико-хімічних змін січених напівфабрикатів з додаванням нетрадиційної сировини та встановлення їхнього терміну зберігання. Показано доцільність поєднання прісноводної риби з рослинною сировиною для розширення асортименту біологічно иінної харчової продукції. Дослідним шляхом встановлено, що додавання нетрадиційної сировини дозволяє не лише удосконалити технологію виробниитва січених напівфабрикатів, а й вирішити завдання отримання продукту підвищеної харчової цінності. Автором було встановлено, щзо розроблена технологія рибних напівфабрикатів значно розиирить асортимент продуктів функиіонального призначення на основі природних компонентів, що дозволить в певній мірі розцирити актуальну проблему переробки сировини внутрішніх водойм Украӥни. 
Ключові слова: рибні котлети, нетрадиційна сировина, чіа, напівфабрикати, органолептичне оцінювання, сенсорна характеристика, флейвор, дескриптори, профілограма.

\section{Вступ}

Розвиток вітчизняної індустрії виробництва продуктів для спеціальних дієтичних потреб населення, насамперед дітей, є одним із найважливіших питань, що потребує першочергового вирішення на державному рівні. Обсяги продукції дитячого харчування вітчизняного виробництва не задовольняють фізіологічної потреби дітей, передовсім тих, що потребують лікувально-профілактичного харчування. Одночасно, за даними органів охорони здоров'я України, виявлено динамічне зростання захворювань, пов'язаних 3 недостатністю травлення, несприйняттям окремих харчових речовин - целіакія, мальабсорбція, єдиним способом лікування яких є раціональні дієтичні продукти, які забезпечують альтернативне повноцінне харчування людини протягом тривалого періоду.

За даними Всесвітньої Гастроентерологічної Організації (World Gastroenterology Organization; WGO), на целіакію у світі хворіє в середньому кожна трьохсота людина. Для повноцінного фізичного розвитку і поліпшення якості життя люди із цим захворюванням повинні постійно споживати безглютенові харчові продукти.

Безпечними для вживання при захворюванні на целіакію вважають рис, гречку, пшоно, кукурудзу, а також менше поширені в Україні амарант, кіноа, саго, монтіна, чуміза, сорго (Lisovska et al., 2017).

Створено низку безглютенових продуктів харчування вітчизняного виробництва, які обмежуються хлібом безбілковим (ДСТУ-П 4588:2006), хлібом безглютеновим (ТУ 8-22-61-88), макаронами “Кукурудзяними”, “Рисовими”, “Гречаними” (ТУ 9149-00117629737, ТУ 9149-011-17629737), “Безбілковими” (ТУ 9149-006-17629737), сумішами для випікання “Кукурудзяними”, “Рисовими”, “Гречаними”, “Безбілковими" (ТУ 9195-002-17629737, 9195-01317629737), печивами “Цукрове”, “Квіткова суміш”, "Гармонія”, “Солене” (ТУ 9131-007-17629737).

Для харчування хворих на целіакію в Україні сертифіковані продукти фірми “DR.SCHAR” (Італія), "BEZGLUTEN" (Польща), “3PAULY” (Німеччина), але їх застосування обмежене через високу ціну (Lisovska et al., 2017).

До однієї галузей рибної індустрії, що найдинамічніше розвивається, можна зараховувати виробництво рибних напівфабрикатів, що пов'язано з проблемою “швидкого харчування” в громадській сфері, з харчуванням школярів, з вимогами скорочення тривалості приготування страв в домашніх умовах. Серед рибних напівфабрикатів представлений широкий асортимент продуктів $з$ котлетного фаршу: котлети, шніцелі, биточки, біфштекси, зрази, тефтелі, фрикадельки, крокети, кнелі, кюфта. Актуальною проблемою є поліпшення харчової цінності та якості напівфабрикатів (Tesak et al., 2016).

Напрацювання вітчизняних учених потребують продовження, особливо в напрямку розроблення технології виробництва безглютенових або адекватно замінених глютеновмісних продуктів для харчування та захисту інтересів і здоров'я категорій населення 3 вибірковим харчовим несприйняттям (целіакією), впровадження сучасних експресних методів визначення глютену.

Метою даних досліджень було удосконалення технології січених напівфабрикатів (котлет), з використанням м'яса прісноводних риб та рослинної сировини (чіа) для дітей дошкільного віку. Для досягнення поставленої мети були виконані такі завдання: розробка нових рецептур рибних напівфабрикатів; розробка дескрипторів, які входять до комплексного профілю флейфору еталону; проведення сенсорного аналізу рибних напівфабрикатів за методом флейвору, визначення хімічного складу готового продукту та показників гідролізу і окислення ліпідних речовин.

\section{Матеріал і методи досліджень}

Об'єкт дослідження - м'ясо коропа звичайного (Cyprinus carpio), насіння чіа ТУ 9164-002-240033452014 (Salvia hispanica), січені напівфабрикати. Предмет дослідження - органолептичні та фізикохімічні показники.

Зразки напівфабрикатів підібрали з урахуванням вмісту в них основних компонентів: рецептура № 2 3 додаванням чіа у 2\%; рецептура № $3-3$ додаванням чіа 5\%, рецептура № 4 - 3 додаванням чіа $8 \%$, контрольний зразок (рецептура № 1) без додавання насіння чіа, лише на основі м'яса коропа.

Процес виробництва січених напівфабрикатів (котлет) складається 3 таких операцій: приймання сировини, сортування, миття, розбирання на філе, подрібнення, приготування фаршу, формування, панірування, смаження (варіння на пару), фасування в споживчу тару, упакування в транспортну тару та реалізація.

\section{Результати та їх обговорення}

Для виробництва рибних котлет були розроблені рецептури, які наведені в таблиці 1.

\section{Таблиця 1}

Рецептурний склад рибних котлет, \%

\begin{tabular}{lcccc}
\hline \multirow{2}{*}{\multicolumn{1}{c}{ Компонент }} & \multicolumn{5}{c}{ Маса компоненту в зразках, г } \\
\cline { 2 - 5 } & Рец. & Рец. & Рец. & Рец. \\
№ 1 & № 2 & № 3 & № 4 \\
\hline Фарш з коропа & 77 & 75 & 72 & 69 \\
Насіння чіа & - & 2 & 5 & 8 \\
Сіль & 1 & 1 & 1 & 1 \\
Яйця курячі в фарш & 5 & 5 & 5 & 5 \\
Хліб Веzgluten білий & 3 & 3 & 3 & 3 \\
Молоко & 5 & 5 & 5 & 5 \\
Яйця для льєзону & 6 & 6 & 6 & 6 \\
Панірувальні сухарі Dr. & 3 & 3 & 3 & 3 \\
Schar Рan Grati & & & & \\
\hline
\end{tabular}

В ході експериментальних досліджень після підбору рецептури з додаванням чіа у відсотковому спів- 
відношенні та за умов теплової обробки була проведена сенсорна оцінка відповідно до міжнародних стандартів ISO. Для створення профілів застосовано метод, викладений в ДСТУ ISO 6564:2005 “Дослідження сенсорне. Методологія. Методи створювання спектра флейвору" (Doslidzhennya sensorne, 2006).

Дегустацію проведено експертною комісією у складі 8 осіб. При цьому оцінювалися дескриптори, які є значущими для споживачів і входили в комплексний профіль флейвору гіпотетичного еталону. Респондентам для оцінки рибних котлет за наведеною шкалою запропоновано 10 дескрипторів, які було розставлено в порядку спадання значущості.

Дегустаційну оцінку зразків рибних котлет проведено за 5-бальною шкалою бажаності та інтенсивності відчуття ароматичних і смакових властивостей продукту: 0 балів - ознака відсутня; 1 бал - ледь відчутна; 2 бали - слабка інтенсивність; 3 бали - середня інтенсивність; 4 бали - сильна інтенсивність; 5 балів дуже сильна інтенсивність (Tesak et al., 2016; Prasol et al., 2017).

Для наочного сприйняття результатів побудовано розгорнуті профілографи флейвору розроблених зразків рибних котлет (рис. 1, 2). Рибні котлети (контроль) характеризувались світло-сірим кольором, солодкосолонуватим смаком, пластичною, щільною за всією масою консистенцією, що свідчить про необхідність коригування їх рецептур для максимального наближення до еталону (рис. 1).

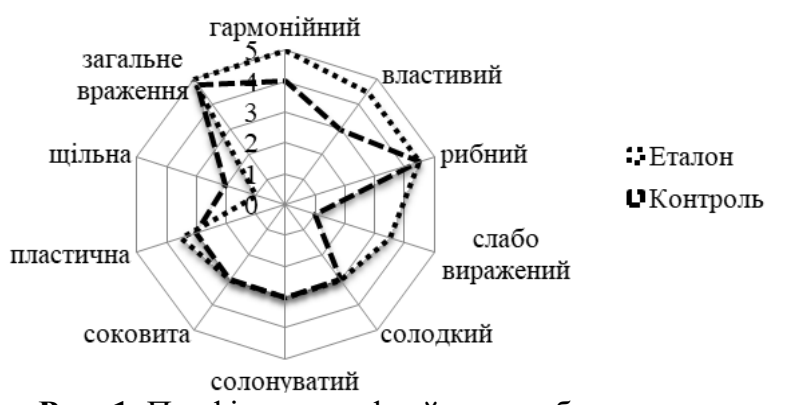

Рис. 1. Профілограма флейвору рибних котлет (контроль)
Порівнюючи розраховану загальну оцінку в балах, дійшли висновку, що найбільш наближеними до еталону $є$ зразок рибних котлет з додаванням насіння чіа -3 оцінкою 35,5 (рис. 2).

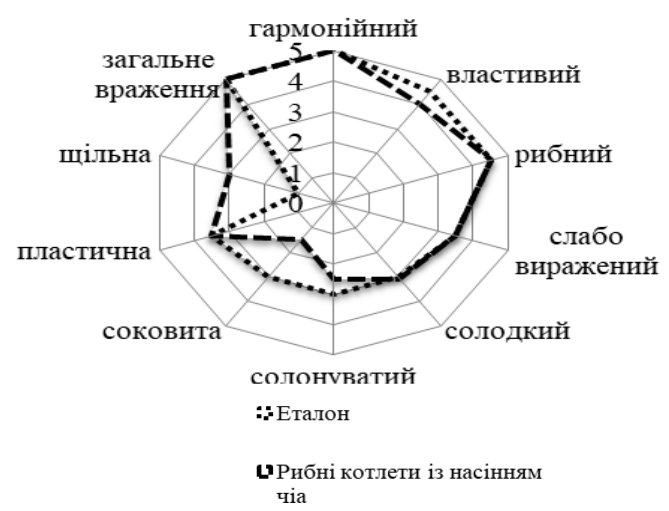

Рис. 2. Профілограма флейвору рибних котлет 3 додаванням насіння чіа

Котлети 3 додаванням насіння чіа характеризуються високими показниками таких дескрипторів, як загальне враження, гармонійний, рибний, солодкувато-солонуватий смак. За показником консистенції рибні котлети пластичні та щільні на розрізі.

Загальний порівняльний аналіз дає змогу стверджувати, що всі зразки рибних котлет мають позитивне загальне враження, гармонійний і рибний смак.

Результати щодо виходу готового продукту і втрат при різних способах теплової обробки наведено в таблиці 3.

Загальний порівняльний аналіз дає підстави стверджувати, що всі зразки рибних котлет мають позитивне загальне враження, гармонійний і рибний смак.

Аналіз загального хімічного складу напівфабрикатів виявив, що вміст білка в розроблених зразках (рец. № 1-3) коливається від 16,20 до 20,50\% (табл. 4). Це пояснюється тим, що всі зразки містять приблизно однакову частку білкововмісних інгредієнтів. Відрізняються вони природою походження інгредієнтів: в контролі - джерелом білка є здебільшого рибна сировина, а в розроблених зразках (рец. № 1-3) - рослинна сировина.

Таблиця 3

Вихід і втрати готового продукту при різних видах термічної обробки

\begin{tabular}{ccccccc}
\hline \multirow{2}{*}{ Номер зразка } & \multicolumn{3}{c}{ Парова обробка } & \multicolumn{3}{c}{ Смаження } \\
\cline { 2 - 7 } & $\begin{array}{c}\text { Маса виробу до } \\
\text { обробки, Г }\end{array}$ & $\begin{array}{c}\text { Маса виробу } \\
\text { після обробки, г }\end{array}$ & Втрата, \% & $\begin{array}{c}\text { Маса виробу } \\
\text { до обробки, г }\end{array}$ & $\begin{array}{c}\text { Маса виробу } \\
\text { після обробки, г }\end{array}$ & Втрата, \% \\
\hline Рец. № 1 & 50 & 32 & 36 & 51 & 29 & 43 \\
Рец. № 2 & 51 & 30 & 42 & 52 & 28 & 46 \\
Рец. № 3 & 47 & 42 & 11 & 45 & 33 & 27 \\
Рец. № 4 & 49 & 34 & 31 & 47 & 32 & 32 \\
\hline
\end{tabular}

Таблиця 4

Хімічний склад напівфабрикатів, \% $(\mathrm{n}=5, \mathrm{P} \leq 0,05)$

\begin{tabular}{ccccc}
\hline Зразок & Вміст вологи & Вміст білку & Вміст ліпідів & Вміст мінеральних речовин \\
\hline Рец. № 1 & $72,50 \pm 5,21$ & $14,87 \pm 0,42$ & $4,15 \pm 0,28$ & $2,37 \pm 0,12$ \\
Рец. № 2 & $70,08 \pm 4,67$ & $16,20 \pm 0,53$ & $11,63 \pm 0,97$ & $2,58 \pm 0,17$ \\
Рец. № 3 & $65,70 \pm 4,67$ & $17,49 \pm 0,53$ & $12,66 \pm 0,97$ & $2,92 \pm 0,17$ \\
Рец. № 4 & $63,80 \pm 6,04$ & $20,50 \pm 0,27$ & $15,52 \pm 0,72$ & $3,72 \pm 0,24$ \\
\hline
\end{tabular}


Вміст ліпідів у прототипі становить 4,15\%, у зразках рец. № 1, 2, 3 - 11,63-15,52\% - за рахунок введення до цих рецептур чіа, що позитивно впливає на смакові властивості розроблених напівфабрикатів i робить їх соковитішими.

Розроблені зразки напівфабрикатів рец. № 1, 2, 3 містять більше мінеральних речовин $(2,58-3,72 \%)$, ніж контрольний зразок (2,37\%). Це обумовлено тим, що компоненти рослинного походження підвищують біологічну цінність напівфабрикатів.

Ступінь накопичування жирних кислот в результаті гідролітичного розкладання ліпідів напівфабрикатів вивчали за зміною кислотного числа ліпідів. Результати досліджень показані на рис. 3.

Дані рис. 3 свідчать, що зміни кислотного числа ліпідів напівфабрикатів під час зберігання протягом 180 днів при температурі мінус $18{ }^{\circ} \mathrm{C}$ мають лінійну тенденцію до збільшення.

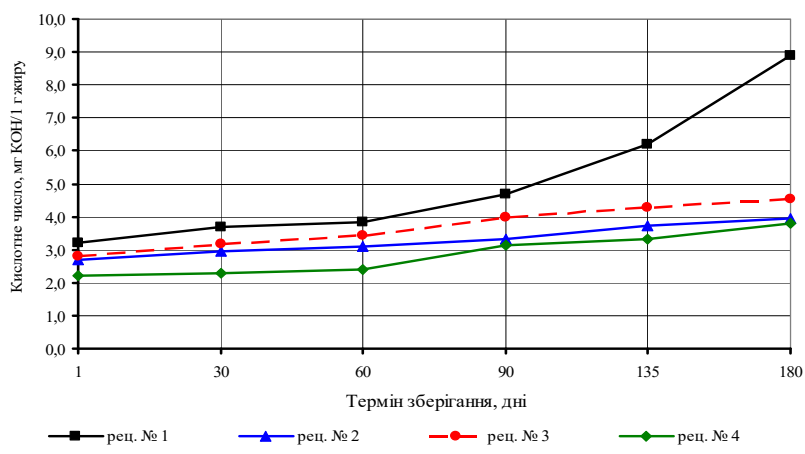

Рис. 3. Динаміка кислотного числа ліпідів напівфабрикатів

Кислотні числа ліпідів прототипу після 60 днів, контрольного зразка після 90 дня зберігання досягають 4,0 мг КОН/1 г жиру і продовжують збільшуватися, що свідчить про інтенсивний гідроліз ліпідів і накопичення вільних жирних кислот у цих зразках. Кислотне число ліпідів зразків рец. № 1, 2 впродовж 180 днів зберігання поступово збільшується і лише до кінця терміну зберігання (180 день) досягає 4 мг КОН/1 г жиру.

Окислювальні процеси в ліпідах напівфабрикатів вивчали за змінами у накопичуванні первинних продуктів окислення - перекисів і вторинних продуктів карбонільних сполук. Результати досліджень змін перекисного числа ліпідів напівфабрикатів під час зберігання показано на рис. 4.

Як видно з рис. 4, динаміка змін перекисного числа ліпідів напівфабрикатів має нелінійний характер. Перекисне число ліпідів прототипу протягом 60 днів зберігання збільшується до $0,03 \%$ йоду, що характеризує жир як свіжий; протягом 60-112 доби холодильного зберігання перекисне число збільшується до $0,06 \%$ йоду - при таких значеннях жир не підлягає зберіганню і після 112 доби, коли значення перекисного числа перевищує $0,06 \%$ йоду, характеризується як жир сумнівної якості. Жир зразків рец. № 1 протягом 90 днів, рец. № 2 протягом 70 днів зберігання характеризується як свіжий; після цього терміну якість жиру погіршується та характеризує жир як такий, що не підлягає зберіганню.

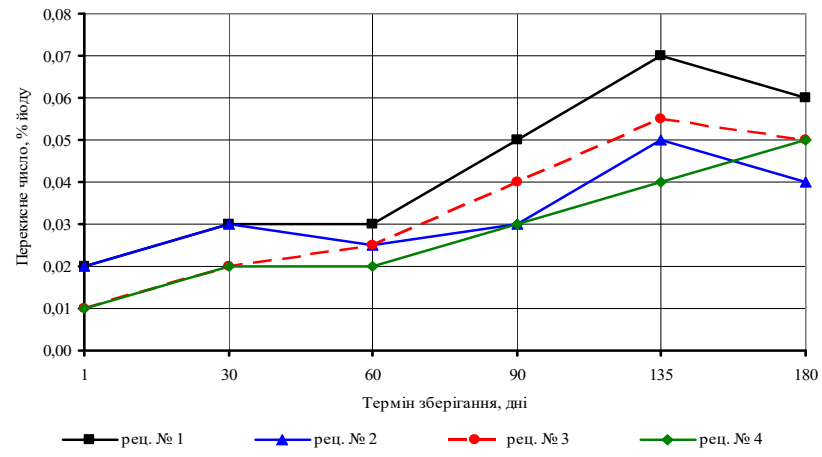

Рис. 4. Динаміка перекисного числа ліпідів напівфабрикатів

Але на відміну від прототипу ліпіди зразків рец. № 1, 2 не набувають критичного значення перекисного числа сумнівної якості жиру.

\section{Висновки}

Встановлено, що харчова цінність напівфабрикатів 3 додаванням нетрадиційної сировини (насіння чіа) характеризується кращими органолептичними показниками та енергетичною цінністю (в 1,4 разу) порівняно з контрольним зразком.

Розроблена технологія рибних напівфабрикатів значно розширить асортимент продуктів дієтичного призначення на основі природних компонентів, що дозволить певною мірою розв'язати актуальну проблему переробки прісноводної риби.

Перспективи подальших досліджень. Отримані позитивні дослідження свідчать про продовження вивчення даної технології і потребують подальших розробок.

\section{References}

Doslidzhennya sensorne (2006). Metodologiya. Metodi stvorennya spektra flejvoru (ISO 6564:1985, IDT: DSTU ISO 6564:2005. [Chinnij vid 2005 - 05 - 25]. K.: Derzhspozhivstandart Ukrayini (in Ukrainian).

Lisovska, T., Derkach, A., Stadnik, I., Suhenko, Yu., \& Vasiliv, V. (2017). Ekstrudovane kukurudzyane boroshno dlya diyetichnogo harchuvannya. Prodovolcha industriya APK, 6, 40-43 (in Ukrainian).

Prasol, I.Iu., Holembovska, N.V., Slobodianiuk, N.M., \& Ochkolias, O.M. (2017). Sensornyi analiz rybnykh sichenykh napivfabrykativ metodom profiliu fleivoru. Naukovyi visnyk LNUVMB imeni S.Z. Gzhytskoho, 19(80), 83-87. doi: 10.15421/nvlvet8017 (in Ukrainian).

Tesak, Yu.I., Golembovska, N.V., \& Ochkolyas, O.M. (2016). Tehnologiya shvidkozamorozhenih napivfabrikativ zbagachenih morskimi vodorostyami. Nauchnye trudy SWorld. Ivanovo: Nauchnyj mir, 3(44), 89-93 (in Ukrainian).

Tesak, Yu.I., Golembovska, N.V., \& Slobodyanyuk, N.M. (2016). Tehnologiya shvidkozamorozhenih napivfabrikativ. Nauchnye trudy SWorld. Ivanovo: Nauchnyj mir, 45(3), 11-14 (in Ukrainian). 